\title{
Effects of Exchange Rate Determinants on Financial Performance of Multinational Companies
}

\author{
Kentis Musimbi Mulinya ${ }^{1}$, Tobias Olweny ${ }^{2}$ \\ ${ }^{1,2}$ Department of Economics, Accounting and Finance, School of Business, Jomo Kenyatta University of Agriculture and \\ Technology, Nairobi, Kenya.
}

\begin{abstract}
Foreign exchange is one of the macroeconomic variables which affect the financial performance of firms. Fluctuations in the foreign exchange rate have an effect on the operating cashflows, investment decisions, profits, sales and a firm's market value. Foreign exchange rate level is determined by various factors which include the balance of payment, terms of trade, inflation and government borrowing. Given the importance of multinational firms to the economy of Kenya, it is crucial to determine the effect of determinants of foreign exchange on their performance. The objective of the study was to determine the effect foreign exchange determinants on the financial performance of multinational companies in Kenya. The independent variables included balance of payment, government debt, terms of trade and inflation. Measurement of financial performance was done using return on equity and return on assets. The study was anchored by the balance of payments theory, Keynesian theory of public debt, theory of international trade and the quantity theory of money. The study sampled four multinational companies operating in the nation of Kenya. The period covered by the study was 2002-2017. Data collected for the study was from both the central bank publications and financial statements of multinational companies. Study data was evaluated using panel data. The fixed effects model was used for the study. The study established that the balance of payments had a negative as well as statistically significant impact on return on assets. The study also established that government debt had a positive and significant effect on return on assets. Terms of trade and inflation were found to have positive but statistically insignificant effects on return on assets. The balance of payment and inflation had a negative and statistically significant effect on the return on equity. The terms of trade was found to have a positive but statistically insignificant effect on the return on equity. Government debt had a positive and statistically significant effect on return on equity.
\end{abstract}

Keywords: balance of payments, government debt, terms of trade, inflation, financial performance, multinationals.

\section{Introduction}

Foreign exchange is among other macroeconomic variables which affect firms in todays' economy. This is as a result of the rapid globalization and integrated markets of various national economies. Change in foreign exchange rate due to unexpected fluctuations may alter the operating cash flows, investment decisions, returns and a firm's market value. Firms with little or no international transactions also stand a chance to face indirect substantial exchange rate exposure (Harper and Aggarwal, 2010). Thus, it is very crucial to put into account exposure to currency movements for the increasing number of local as well as multinational companies (Helhel, 2015). Taking exchange rate effects and comparing with the percentage of operational cash flows, the oscillations over time and the magnitude of possible repercussions of foreign currency exposure turns out to be obvious. Some nations, such as China and India report insignificant effects of rate of exchange on cash flows in large domestic firms. They argue that the multinational companies in the US, Europe, Japan and Korea exhibit variable success in management of impact of cash flow. In order to be at par with the rules of the Communiqué, some countries' enterprises eg Taiwan, which have factories, subsidiaries and branches overseas need to include their profit and loss statements in financial reports every year end (Korsby and Nevoldsen, 2014).

According to Korsby and Nevoldsen (2014), it is believed that increase or decrease in rate of exchange can affect multinationals' value by affecting their cash flows from operations, their foreign assets and obligations and hence their financial performance. However, a lot of discussion is still going on the subject of exchange rate and multinationals' value. For a number of firms, exchange rate movements cause major uncertainties. The financial analysts, economists, and corporate managers hold the opinion that exchange rate has an impact on firm's value and its stock price. The structures of liabilities of multinationals have dramatically changed due to globalization, securitization, innovation and deregulation. Due to this dynamic change, investment projects are now being financed through methods that were not imagined only a few years ago (Froot, 1990). This change has an effect on financial performance of multinational companies due to the change and growth in activities in these companies. An unexpected change in exchange rate leads to change in costs, income, receivables and payables in other currencies other than firm's local 
currency (Eun \& Resnick, 2014). If the local currency appreciates value of multinationals decreases and if it depreciates, value of multinationals increases. However, as (Bhuiya, et al., 2015) put it, researches related to this contradict. Some support this theory while some say the opposite.

The MNCs in the Sub-Saharan Africa grew at $30 \%$ annually from 2006 to 2009. This is unlike the growth of Poor's and Standard largest 500 companies in America. The sales revenue of these countries dropped to below 10\% in 2006 and 2007; in 2008 it stagnated and became negative in 2009. This is as per initiative for Dalberg Global Development Advisors and Global Development, 2011. As a result of many Kenyan firms becoming vulnerable to fluctuations in foreign exchange rate, the Kenyan economy is constantly growing in international trade and is becoming more and more open (Noor and Abdalla, 2014). For example ABB Ltd prioritized India and made sure that global heads at top positions held active posts in the Indian board for faster decision-making. The reasons for the financial growth of these countries have been attributed to the following: First, these companies made India a top priority and made sure that active positions were held by senior global heads in the Indian board for faster decision making. This was adopted by ABB Ltd. Secondly, these companies tailored their goods and services to suit the Indian Customer needs. Thirdly, these companies have the capability to adapt global, reputable structures which give local innovations the support needed. For example, GlaxoSmithKline Plc. (GSK) had its research and development on the global scene and it has excellent products and uses huge global channels of distribution. Fourthly, most MNCs cannot allow the rule of bureaucracy to pin down their potential in India. For example the LG Company empowers the local managers to make key decisions, thus quicker action. Fifthly, the companies embrace local partnerships which assist in attaining knowledge of local market their quick access. For example Commins Inc. had a joint venture with Crompton Greaves Ltd and Tata Motors Ltd (From live mint (2016).

The exchange rate refers to rate of conversion of the currency of one nation into that of another. The fluctuations in market forces of supply and demand of currencies may make this change to occur daily. The exchange rate is an expression of equation of national currency in regards to foreign ones (Piana, 2001). Foreign exchange rate forms one of the most crucial means by which the relative economic health level of a nation is determined. A nation's foreign exchange rate plays a role in its economic stability hence frequently followed and analyzed. The economic stability will consequently affect the overall health of firms in a nation, both domestic and multinationals including their financial performance. Exchange rate determinants are the factors which lead to positive or negative effect on exchange rate. These factors include and not limited to inflation rate, interest rate, terms of trade, balance of payments, government debt, recession, political stability and speculation (Bergen, 2017). This research will therefore look at four of these factors which include balance of payment, terms of trade, government debt and inflation rate.

A multinational company refers to a business organization which has value added holdings overseas (Yusaff et al., 2012). A multinational company shares technology, managerial talent, capital and marketing skills for production with foreign countries. According to Dunning, (2008) a MNC is a firm that participates in foreign direct investment (FDI) controlling or owning shares in more than one nation. MNCs represent a large percentage of economic power in the US and the entire world. Due to their global orientation and size, they play a vital role in financial markets internationally (Froot, 1990). Thus, the financial performances of MNCs need to be closely checked. Fluctuations in foreign exchange rate exposure has an impact on monetary assets' net value with constant nominal payoffs together with real assets' value of a firm (Alssayah1 \& Krishnamurti (2013).

Financial performance is defined as the degree of performing financial objectives or the extent to which these objectives have been achieved. It analyzes the relationship between a firm's operations and its policies in monetary dimension. It measures a company's total financial status for a specified time period. It can also be used to give comparison for similar firms in one industry or comparison of sectors or industries. It gives subjective measures of how well an organization is able to use its assets from the basic business and give revenues. Profitability is commonly measured when evaluating a firm's financial performance. This assesses how well or bad the management invests in the overall capital of the organization and raising funds. A firm having assets and liabilities in various oversea locations may have a crucial role in increasing the exposure of the firm to varying exchange rates. This basically affects both domestic and MNCs (Jong et al., 2006).

According to Salifu et al., (2007), various researches have continued to comprehend the exposure level and determinants to fluctuating exchange rates of firms due to their impact on business activities of the risk of foreign exchange and the difficulty to predict changes in foreign exchange trading areas. Empirical research shows that rapid and unpredictable rates of exchange have an effect on profits and revenue of local and MNCs (Muller \& Verschoor 2006). Due to constant outsourcing activities to foreign nations, firms incur foreign currency costs (such as taxes, wages and material). It is therefore crucial that financial managers are acquainted with the magnitude of this (Abor, 2005). Also, firms not engaging in outsourcing and foreign exchange are vulnerable to changing rates of exchange by competing with MNCs, macroeconomic conditions and foreign competitors. Thus, the business performance and income statements of both foreign and local companies are affected by exchange rates fluctuations despite having indirect financial exposure only (Parsley \& Popper 2006). 


\section{Statement of the Problem}

There has been a constant fluctuation in the financial performance of multinational companies as well as local companies. Some have a rise in performance; some have a declining performance while others have a constant performance.According to the financial service segment the return on equity of most multinationals have been experiencing a fluctuation between the years 2011 and 2015 . A recent study on effect of exchange rate determinants showed different impacts of these determinants on financial performance. This study done by Otuori (2013) on Kenyan commercial banks revealed a significant and positive impact of external debt and interest rate on performance while inflation rate had negative significant impact on performance. In Nigeria, the Naira value reduced remarkably against the dollar in the US from 2006 onwards due to decrease in foreign inflows due to inordinate decrease in oil demand (Zubair, 2013). In India, the value of the rupee depreciated to as low as 68.85 against the dollar in August of 2013. In 2014, the rupee appreciated to 70 per dollar. In a study on the currency changes on the manufacturing firms in India (Dhasmana, 2014), real exchange rate changes had large impact on performance of organizations in the short run due to import costs changes rather than export competitiveness changes. However, there is no any empirical evidence on effect of exchange rate on Indian firms' performance.

In the energy sector, exchange rate risk has various impacts on energy firms. In a study on exchange rate exposures on energy firms in Turkey, Ozturk, et al. (2015), in their sample of 9 energy firms, only two seemed to be vulnerable to risk of exchange rate while the rest were not affected by these changes. It was argued that the different exchange rate impacts may be due to firms' size. There has been a fluctuation in profitability of Coca Cola Company since the year 2007 to 2016. The 2013 financial statements of Coca Cola Company show that the revenues had a decrease of $2 \%$ compared with 2012 while the net income showed decrease of 5\%. This decrease in operating revenues was because of unfavorable foreign currency variations in the US (Zhang et al., 2014).

Other empirical studies show that movements in exchange rates have an effect on profits and revenues of local and multinational companies (Verschoor \& Muller 2006). This is due to outsourcing activities to other nations where companies incur costs in currencies of other nations. Some studies have not yet established a strong relation between returns of firms on stock markets hence market value and movements in exchange rates (De Jong et al., 2006).

It is assumed that exposure for exchange rate has an effect on multinationals' value. Also believed that a rise in local currency value causes a fall in multinationals' value by the reducing value of foreign currency controlled cash flows as well as assets and vice versa. However, some empirical studies have found this not to be true. One study to investigate whether the above is true was done by Haque et al, 2015 on analysis of performance of $103 \mathrm{UK}$ MNCs. This study investigated stock's return impact on value of a firm. The results indicated no large relationship between pound's value and that of MNCs in the UK. Only a few of these firms had a large relationship between their value and that of pound.

From the above, it is evident that foreign exchange movements have an effect on firm's financial performance of firms, thus causing fluctuations in the performance. However, there is no evidence of how much these determinants affect the financial performance of multinational companies. Other reasons have been attributed to financial performance of firms such as financial leverage, recession and outsourcing but few have touched on exchange rate determinants. It is for this reason that this research investigated the relationship between determinants of foreign exchange and financial performance of multinational firms.

\section{General Objective}

To assess the effects of exchange rate determinants on financial performance of multinational companies.

\section{Specific objectives}

i) To evaluate the effect of balance of payments on financial performance of multinational companies.

ii) To determine the effect of government debt on financial performance of multinational companies.

iii) To establish the effect of terms of trade on financial performance of multinational companies.

iv) To investigate the effect of inflation on financial performance of multinational companies.

\section{Theoretical Review}

\section{The Balance of Payment Theory}

This theory holds that prices of international money expressed in domestic country's money are determined by free forces of supply and demand in the market for foreign exchange. Therefore, the external value of a nation's currency depends on the currency's supply and demand. This theory states that forces of supply and demand are determined by several items found in a country's balance of payment (Nirav, 2012). As per this theory, a deficit in the BOP causes a fall in exchange rate, where as a surplus in BOP causes a stronger foreign exchange reserve, causing a rise in local currency as related to foreign currency. A deficit in a country's BOP shows that demand exceeds supply of foreign exchange. Consequently, the international money's price expressed as home currency must increase, that is, exchange rate of home currency falls. A surplus in a country's BOP shows a larger demand for domestic currency in another country more than the present supply. This result in rise in price of local currency expressed as international currency, showing that there is an improvement in the rate of exchange (Nirav, 2012). Thus, the BOP implies that the exchange rate is influenced by the BOP connoting supply of and demand status of foreign exchange of the concerned nation. As such, this theory is designated as 'Demand Supply Theory'. It implies that exchange rate is a 
function of supply of and demand for international money and not merely the function of prices of two nations.

The model of Meade-Tinbergen-Mundell (1951) or rather model of optional combination of economic policy measures opposes the achievement of two goals (external and internal balance) using a single instrument. Instead, this theory uses two instruments for achieving two goals. These two instruments are devaluation and financial policy. In his theory, Mundell linked the expenditure effect (income) to the approach of elasticity. He suggested that devaluation cannot better the BOP under full employment conditions without a proportionate decrease in the absorption and real wages. He proposes that the financial policy regulates the internal balance and devaluation stabilizes the balance of payment. Tinbergen reacts to Mundell's proposition by introducing the view of many instruments as there are goals in the economic policy. Mundell then divided the financial policy into the fiscal and monetary policies. Thus expanding the number of economic policy instruments which affect the current balance as well as the capital's international movement. Although Mundell did not link the money market with the capital's international movement, he came up with the basics on which basic approaches to the exchange rates and BOPs have and are still building, more on the portfolio approach.

After 1971, there was the monetary approach to the BOP Rabin and Yeager (1982) which was implemented under fluctuating exchange rates conditions. This acquired the elements of exchange rate monetary theory. This theory was founded on the arguments of global monetarism which develops from the relations of monetary supply and demand as exchange rate basic determinants. In the long run the monetary supply is variable while monetary demand is stable. Growth in MS has an impact on absorption, increasing it and leads to rising of prices. Over a short period, the deficit in the BOP causes currency depreciation. This deflates the supply of the nominal monetary which decreases the available framework approach hence stabilizing the BOP. The currency exchange rate is a function of MS and relative prices. Here, prices are changed on a worldwide scale while the variable magnitude is the exchange rate. The portfolio approach is a step forward to the monetary approach and foreign exchange rates monetary theory. It prioritizes the monetary and capital market. This approach accepts certain views of global materialism such as the law of one price full employment, international commodity market integrity and demand for money stability. It also develops from new propositions such as international capital markets integrity and important interest rate roles in the international movement of capital process. The monetary demand function depends on the GDP level of any economy, and in no case it is only a monetary variable. MD is the expression of real economy of a nation (Arkolakis, 2014). We also have failed economic policies over the world. Such include the Latin America and the Yugoslavia's issues in the 1980s which was enhanced and worsened by the unfit mix of the economic policy. According to this theory, the foreign exchange demand comes from the balance of payments' debit side, while the foreign exchange supply from credit side. Since it assumes that supply and demand for international currency is determined by the status of the BOP, it shows that demand as well as supply is determined mostly by factors independent of variations of exchange rate or monetary policy. Accordingly, with supply demand schedules, their point of intersection is the determinant of a currency's equilibrium exchange rate. The lower the currency's price, the greater its demand; leading to downward sloping of the demand curve. Whereas the, supply curve slopes upwards starting from left to right showing that a decrease of a currency's price leads to a contraction in its supply.

The supply and demand curves of the currency of a country intersect at a point determining the rate of exchange where quantities of supply and demand are equal. This is the rate of equilibrium. When exchange rate is high, supply exceeds demand and thus is lowered by the excess supply. This continues until the two are in equilibrium where they intersect. In lower exchange rate, the reverse is true. Therefore, the changes in supply and demand or both have an effect on equilibrium exchange rate. This is how this theorem brings about the determination of the exchange in the equilibrium analysis (Stojanov, 2006).

It is taken that exposure for exchange rate has an effect on the multinationals' value. Also believed that a rise in local currency value leads to a fall in multinationals' value by the reducing value of foreign currency controlled cash flows as well as assets and vice versa. When exchange rate is high, supply of local currency is high leading to a decrease in multinationals' value and vice versa.

\section{Keynesian theory of public debt}

The great depression in the 1930s which caused the then economic crisis partially led to development of Keynesian theory of public debt. Traditionally, it was viewed that persistent unbalanced budgets led to public debt rising rapidly that led to financial stability of a nation gradually gave way to the notion that a large national debt is regarded as an asset and not a liability in the country and that constant deficit spending was necessary to the country's economic property (public debt assuming full employment). Keynesian attack on budgeting and public finance classical principles logically extended the Keynesian reaction to the conception that at full employment, the economy tends to be at equilibrium. Keynes argued that in case of unused resources, which were not affordable to the private sector; these resources could be used hence unbalancing the budget. Keynes argued that a rise in public debt due to multiple effects raises a nation's national income. In this, public debt was linked to deficit financing, thus authorized the country to borrow for all reasons increasing the effective demand hence increasing employment and output. He did not separate the productive from unproductive expenditure like the classical theory. According to him, consumption borrowing was as good as borrowing to invest in productive goods since consumption expenditure caused a rise 
in investment. Keynesians' view reached its culmination in Learner's view of Functional Finance (1948). According to him, he perceived government expenditure and revenue plus debt particularly as mechanisms to regulate community expenditures. He viewed these as instruments to achieve stable employment. Expenditure and tax were to be decreased or increased to support a country's spending rate accordingly, debt was to be given to the public at a price in order to take in their unused balances and bought back to raise liquidity during depression.

The Theory of Functional Finance states that the national debt's size has no effect at all, and that though there has to be payment of large interests, these; however, do not impose any weight on the community. The weight concept has a certain significant advantage of borrowing by the public. The economic impact of public borrowing needs to be analyzed according to the nature of the purpose for which is to be used and according to its income generating capabilities. The importance to the public debt net burden was given by the modern theory. This theory further held that additional income due to rise in expenditure financed by debt assists the taxes payment to debt payment. During unemployment, a rise in government debt attributes to a nation's current capital which would not have occurred. Also, the mentioned modern theory holds that debt promotes more and more developed institutionalized saving sectors such as stock and capital markets, insurance companies and banks. The public can also invest savings in government bonds as a result of growth of public debt. According to Buchanan (2008), this mentioned modern theory regarding public debt was called New Orthodoxy. According to him, it is based upon three basic assumptions. First, the public debt creation does not constitute any kind of transfer of basic real burden to the generation in future. Secondly, the comparison between public and private debt is not correct. Thirdly, there is a sharp and significant difference between external and internal debt. The Keynesian theory also has led to desirable or sustainable public debt question, which is controversial to Keynesian theory. The financial crises which occurred in 2007 have caused an interest in Keynesian theory partly because of deteriorating balance sheets of the public sector in the course of wider economic and financial crises. According to Aspromourgos (2007), the general interest rate level is no longer determined by the prevailing real forces in orthodox way, but by interaction of monetary policy and money markets. Keynes theory implied negatively that in an economy that is competitive, there is no tendency that is automatic towards none involuntary unemployment. It also negatively implied that fully grown capitalism shows a constant tendency general towards insufficiency of the effective demand. According to Hussein \& Dewan (2001), debt impacts directly the economic growth, hence financial performance of multinational. This is because, if the amount borrowed is optimally used, investments are expected to increase. As long as the borrowed funds are utilized for investments that are productive and are not affected by macroeconomic instability, policies which change economic packages or considerable adverse shocks, there should be increase in growth and this should allow timely repayment of debt. Debt also has an indirect impact on investment whereby it reduces the resources available for investment through servicing of debt. In addition, debt can also bring about the same impact as that of implicit tax on a country's resources thus creating a burden on future resources through reduced income from private capital stock that is lower.

\section{International trade theory}

Earlier Bhagwati (1958), attempted to find out the effect of trade on growth in his immiserizing growth model. Despite some assumptions, Bhagwati pointed out the relevance of movements of terms of trade relating to trading countries growth levels. However, Bhagwati's model prevailed in a country that was growing faster or in isolation compared to its trade partner. Terms of trade came out as powerful tools to show the unequal trades for developing nations. The New trade theory strategic trade component gained recognition especially in the US, during the 1980s, in the policy of public. Generally, it was accepted that the" Vagaries of history" and not resources determines a nation's produce and exports. Hence the role played by "history and accident" were regarded as essential in determination of a certain industry in the world map (Krugman 1994). Regardless of the innovative critique to the traditional theories of trade, the new trade theory has remained as fully in agreement with the traditional theory. This theory explores extensively and creatively the exceptions proposing that traditional theory may conquer with its results which were taken to be standard (Davis and Darity, 2005). As across, the limitations still remain embedded in this new theory due to its excess reliability to the old (Bhattacharjea, 2004). Surely, the rules of the free trade for the new trade theory or traditional variety or with their approach that is positive towards world trade did not address the changing impacts of trade openings in development and growth of both the third world and trading countries. These resource allocation theories that are optimal for free trade, under the HOS theory and the standard comparative theory, both did not recognize the awareness brought about by Ricardo and Smith on uneven nations development (Davis and Darity, 2005). This affects the increasing returns analysis, market size and innovation in Smith and the Corn Law Debate as in Ricardo.The three deviants differentiate this new model from the old models of trade such as the HOS Heckscher-Ohlin (1950) (and later Samuelson, 1954). This new model is viewed as predictor of trade patterns across countries basing on factor prices and pre-trade commodities. Rising returns if there is connection to production price reduction are same as those within the organization, was regarded as not compatible to the equilibrium which was competitive. This is due to the fact that producers benefiting from internal scale economies can influence the market through control of market share and prices. The strategic trade notion of Brander and Spencer 


\section{"Effects of Exchange Rate Determinants on Financial Performance of Multinational Companies"}

(1985) was as result of imperfect markets which have capacities for reciprocal dumping by countries in the market of each other (Krugman and Obstfeld, 1992). According to Anderson et al., (1994), product differentiation interferes with HOS trade model basic properties with economies of scale. As demand rises in any country for each variety of same industry production, there is creation of chance for trade for industry across the nations. Such trade for the industry is also possible to occur in segmented markets and price discrimination in firms, for revenue maximization by use of different demand elasticities which exists for similar goods in the two different countries. The above describes a situation where different elasticities occur to demand curves in the two nations. Having the scale economies within the nation, there occurs a possibility that is parallel when countries doing well in goods production have more advantage that those not doing well in production by producing at lower prices. Alternatively, this also forms the background for aggressive trade that is strategic for nations that have already developed industrially. Also, preferences for Dixit-Stiglitz have been used (for which function of utility represents whereby utility rises according to varieties consumed and not each variety's quantity) (Bhattacharyya, 2004) to make a conclusion that the variegated consumption basket welfare effect exceed any losses since development of the autarky all the way to the free trade. Small scale producers not able to afford scale economies may be affected by these losses which allow them to cater for costs that are fixed. For economies of scale internal to the industry and external to the firm, there is global span achieved due to location. This, according to new trade theory allows for global scale cost reduction whereas production from areas where cost efficient is less dislocated. According to Krugman (1981), free trade depends on what is attained by all trading countries by getting rising returns which happen on a worldwide scale. However, trade gains occur with rise in output of industries within trading nations which benefit from national scale economies. Likewise, trade gains also occur to industries that benefit from economies in international arena. Particularly, small economies which cannot get such economies should open up in order to gain. Therefore, there may be losses or positive gains with outside economies in the international market for countries which can benefit from the economies. The above is achieved also for countries with identical pre trade prices and resource endowments. In such a case, small nations will benefit more due to expanding markets and also the international market avails external scale economies (Darity and Davis, 2005). The theories of HOS variant, neo-classical trade and new trade theory all did not address the growth as well as development issue of comparing equilibrium states that are static by viewing change and not the process in the historical time which cannot be reversed. What theories in the new trade theory put across did not include circumstances where there can occurresource endowment changes consumer preferences or technological possibilities (Bhattacharjea, 2004). None of all these theories put emphasis on issue of fluctuating income distribution with restricted or free trade. According to Sunanda (2010), the trade theory's rigid framework started being questioned from different angles. The New Trade Theory as development from the old trade theory introduced the economies of scale in production. This was majorly supported by the rising returns to scale on mutual benefits and international trade pattern. This related to the firm's size and structure of the market which were connected to the potential of reduced production prices. To acknowledge the impacts of economies of scale above, there is need to have a concern on the imperfect markets which often is associated with economies of scale. Under monopolistic competition, products are differentiated leading to further deviation from the competitive model. This would result in competition that is imperfect with oligopoly, monopoly or monopolistic competition. The oligopolistic competition has led to use of principles of strategic trade which came instead of the strong overtones in policy for the subsequent years. Incorporation of rising returns to scale problems which is important to industrial firms' expansion had earlier developed. In his attempt to avoid the possible multiple equilibria problem under rising returns, Marshall assumed the historical cost concept and thus are irreversible over a period of time. He also avoided the proposal by Pigouvian on taxes and excesses for consequent decreasing and increasing costs for industries. Similarly, Knight and Graham had to deal with impacts of rising returns on trade (Sunanda, 2010). According to Sunanda (2010) there have been complex problems in the New Trade Theory in the more recent times which incorporated rising returns to scale. This is especially with departure explained in terms of formulation of neo classical HOS. Thus these theorists had to bring back the HOS Theory. Particularly they had to focus on power to predict patterns of trade during imperfect market competitions and rising returns. Another problem was a breakdown for a market that was perfectly competitive having internal economies of scale to the organization. The change rules out the model assumptions and the major conclusions made according to its trade patterns power of prediction and its propositions from protection, real wages together with equalization for factor price and change effect in factor endowment propositions. Efforts to restore the predicative power of these theories within the new theory circles did not yield any fruits in terms of its generality. Dwelling, studied the possibilities for a secular decrease in the terms of trade of commodity. International activities increase day by day in terms of maximization of profits and minimization of costs. As a result of the positive effect on nation's growth and development, governments are taking up foreign trade especially policies that promote exports. Thus, businesses are now more interested with foreign activities so as to attain their targets. Thus international trade affects the multinationals. Some companies, especially because of the cost advantages of raw materials and materials, are only engaged in import activities while some companies are only interested in export activity to achieve higher profitability and 
sales level. However, some companies are importing and exporting. Preferences related to export and import activities affect the level of internationalization of companies (Berberoğlu, 2017). The significance of the terms of trade in a nation's economy and development were emphasized in literature for economics as from the time of Adam smith (1776) who pioneered inquiry into the nations' wealth and its causes. The correlation existing between international trade and economic welfare of a nation is important since there is need of export of goods and services so as to create revenue for financing goods and services that are imported (Morgan \& Katsikeas, 1997).

\section{The Quantity Theory of Money}

This theory states that a change in aggregate level of aggregate price is determined by a change in quantity of money that is in circulation. David Hume (1711-1776) gave the initial analysis of how a monetary change spreads from one economic sector to another, thus changing the relative price and quantity $\mathrm{He}$ gave a considerable elaboration, extension and refinement to this theory. Ricardo David, (1772-1823), argued that such disequilibrium effects are not important in the equilibrium analysis in the long run. As the Balloonists leader, he claimed that the Britain inflation was solely as a result of the irresponsibility of the Bank of England regarding the money issue. This happened in 1797, when Britain took an inconvertible paper standard leaving the gold standard one. Ricardo was against any discussions on the likely employment effects of money and the beneficial output (Totonchi, 2011). Irving Fisher (1876-1947), gave out the function of MV=PT which among others, such as the cash balance equation which is in line with the upcoming use of mathematics in the neoeconomic analysis defines the conditions underlying the proportional postulate. Fisher and other economists showed that control of money could be obtained through control of exogenously determined measured stock of money in high power, in a fractional reserve banking system. This theory reveals a relationship that is positive between money supply and price levels. That is there is an equal and proportional change in price level and money supply. As per this theory, there is a belief that inflation is caused by an expansion of sully of money in an economy (Ifeanyi \& Chukwuma, 2016). This theory was relevant to this study in the sense that most failures of business are due to unplanned fixed assets investments which could have been easily detected if rate of inflation was factored to obtain the real required rate of funds to be invested, more so in developing nations where infrastructures are inelastic.

\section{Empirical Review \\ The Balance of Payment}

A research was done by Ahmad et al (2014) on impact of rate of exchange on the balance of payment in Pakistan. The results indicated a significant positive relation of the variables. The exchange rate was statistically significant and impacted positively the BOP. Thus the exchange rate cause BOP and
BOP does not cause exchange rate. Also, a research study was done by Muftau and Iyoboyi (2014) on how exchange rate depreciation affects BOP in Nigeria. The results indicated a longterm equilibrium relation of BOP, EXCR and other variables. The results which were in favor of the general rapid reaction function suggested that an innovation on standard deviation on the rate of exchange leads to a reduction in positive BOP in the long-term and medium term whereas the variance decomposition results showed a significant variation in the Nigerian BOP was not due to changes of exchange rate movement. This indicated that the exchange rate depreciation which was dominant in the country from the mid-1980s was not very necessary to improve the country's positive BOP. Another study done by Ali (2010) on the BOP of Pakistan a monetary phenomenon-was econometric evidence. The results indicated that monetary aspect is not necessary in determination of Pakistan's BOP. Instead, there were significant relationships between exchange rate, inflation, foreign assets and BOP which was a significant positive relationship. A strong negative relation of local credit, supply of money and BOP was established. Also, an insignificant relation of BOP and interest rate was realized. Thus, the BOP was found not to be a purely monetary phenomenon. Another study was done by Ibarra and Blecker (2012) on liberalization of trade and the BOP constraint together with intermediate imports-the Case of Mexico. The results indicated that during the years of 1960s, the BRER index was stale relatively, with an index of about 84, and then increased in two periods in the $1970 \mathrm{~s}$, then followed by crisis of currency and high devaluations. After the issue of debt at the start of 1980 s BRER moved to 127 in 1986, hence the trend of liberalization for the period between 1960 and 1986 led to depreciation. After liberalization, this trend reversed and in 2006 the BRER index fell to 78. Another research was done by Odili (2014) on Exchange rate and BOP-Econometric Investigation and Autoregressive Distributed Lag (ARDI) in Nigeria. The results indicated a significant positive relation of both the short and long run of BOP and exchange rate. Further, it indicated that depreciation improves BOP and the Marshall Lerner (ML) condition was found to subsist for Nigeria.

\section{Government Debt}

Ahlborn and Schweickert (2015) did a research on growth of economy vs debt of the public -the Economic systems matter. The findings showed a great heterogeneity between country clusters of the two variables. This relationship differed between nations with distinct GDP per capita, that is, different development stages with equivalent institutional quality levels. There was a linear but negative effect of debt of the public on growth in the long run in poor and underdeveloped nations. Mencinger, et al. (2014) did a research on increasing debt of the public on growth of economy in Europe. Their research explored the mechanism of transmission about the short term growth impact on debt of the public. It analyzed the direct impact of high debt on European nations economies increase which were in the then crisis of sovereign debt. The results 
indicated a nonlinear effect of debt of the public ratios on yearly GDP per capita rates of growth which were statistically significant. Also, the turning point for the debt of the public to GDP where positive impact of accumulation of debt of the public becomes negative was about the range of $80 \%$ and $94 \%$ for the member states which were regarded as old and between $53 \%$ and $54 \%$ for the member states termed as 'new'. This study, however, analyzed the direct impact of high debt on growth of economy for European Union nations and not on financial performance of a firm. Checherita and Rother (2010) did a research on the growing and higher debt impact on growth of economies in Euro Area. The findings showed a non-linear effect between growth and debt with the point of turning above which ratio between debt of government and GDP has a harmful impact on growth in the long term, between 90 and $100 \%$ GDP. The confidence intervals of the turning points of debt indicated that negative results of growth of higher level of growth may start already from around 70 to $80 \%$ of the GDP. Mutai et al., (2008) researched on local debt's impact on economy-a case of Kenya for a period between 1996 and 2007. The Kenyan debt composition was realized to change favoring local debt. The study on local debt's impact on real output indicated an insignificant but positive effect on growth of economy. Another study was done by Graham et al., (2014) on how government borrowing affects Investment and Corporate financing.in the US government. The results indicated that over the last century, the lending of the US federal debt of the government yields a large impact on financial policies for the corporate and the balance sheet by its effect on portfolio's distribution on investors and the different assets' relative prices.

\section{Terms of trade}

A research was done by Heshmati and Sun on international trade effect on China Economy. It was found that an increase in global trade participation leads to dynamic and static influence in China hence rapid economic growth. Both the trade structure and volume of international trade towards exports of high class leads to a positive regional productivity on the Country. A research was done by Muuls and Pisu (2007) regarding exports vs imports at the firm's levelBelgium. The findings indicated that in manufacturing, the level of imports and exports is almost the same contrary to previous facts that exports had higher levels. It was also found that number of firms decreased as export destinations diminishes, or imports increases. Another research was done by Fosu (2011) on TOT and two government economies. The results indicated TOT impacted Botswana output positively and Nigeria negatively. Another study was done by Schaur and Munch (2005) on export promotion effect on level of organization's performance in the Danish government. The results showed that promotion of exports by the Danish economy raises the value added to a great extent, employment together with value added for every employee in the Danish organizations comparing council firms with self-selected firms. Another study was done by Wacker, et al., (2014) on
Foreign Direct Investment, Terms of Trade and Development, Intra-Asian Case-Kickking Away the Ladder. The paper addressed the issue why FDI have a general positive effect on TOT of developing countries apart from South Asia. The results indicated a positive relation of GDP and FDI. The results indicated that the South Asian countries generally advanced down the ladder. They also indicated that late entries in the international markets cannot develop as fast as more advanced nations, instead, they must use adapted methods. Another study was done by Konstantin, et al. (2014) on Foreign Direct Investment, Terms of Trade and Development, Intra-Asian Case-Kickking Away the Ladder. The paper addressed the issue of why FDI have a general positive effect on TOT of developing countries apart from South Asia. The study utilized secondary to collect data from World Bank 2012. The population consisted of terms of trade index, Net FDI and GDP of East and South Asian nations for a period from 1980 to 2010. The sample covered 490 observations in a total of 52 developing nations. Regression model data analysis was done. The conditional rate of growth was regressed on mean of the FD Inflows/GDP of the sample period. The results indicated that GDP and FDI relate positively. The TOT developments were obtained from growth rates and a regression was done on the FDI. The results indicated that the South Asian countries generally advanced down the ladder. The findings also indicated that late entries in the international markets cannot develop as fast as more advanced nations, instead, they must use adapted methods. Also, globalization may maintain North South traditional behaviors in rising South patterns.

\section{Inflation rate}

Ifeanyi and Chukwuma (2016) did a research on how inflation affects value and profitability of chosen organizations firms for manufacturing in Nigeria. Analysis of variance and the multiple regression models were utilized. There was a strong but negative relation of ratio firm value and inflation and small negative relation of return on assets and inflation. There was also an insignificant relationship between return on assets value added economy. Oleka, et al. (2015) did a research on how inflation affects organization's performance, Nigeria. The study established how inflation affects profitability of entities like banks. The results indicated that reported profits and inflation did not have a significantly positive relation as well as return on equity. This indicated that inflation lowered the value of firms. Ogeto and Osoro (2014) researched on how macroeconomic fluctuations affect manufacturing firms' financial performance listed in NSE, Kenya. The findings showed a significant effect of interest, inflation and foreign exchange rates on manufacturing firms' performance. Maigua and Muoni (2016) did a research on how rate of interest determinants influence performance of Kenya commercial banks. From the results, the inflation, the exchange and discount rates influenced positively while reserve requirement had negative influence. Thus higher levels the inflation, the exchange and discount rates caused high performance of the 


\section{"Effects of Exchange Rate Determinants on Financial Performance of Multinational Companies"}

banks while high ratio of reserve requirement caused a lower performance. Another study was done by Patjoshi (2013) on inflation effect as regards financial performance measures in manufacturing industries in India. The findings indicated that the profitability level of manufacturing industry in India after adjustment for inflation was lower according to the profitability measures done by the use of costs of the historical basing on the statements. Also, the inflation results varied greatly on the production companies. The study however focused on profitability using historical cost basing on the statements but it did not consider other methods of cost estimation.

\section{Research Methodology \\ Research design}

The type of research design to be used was causal design. This is defined in simple terms as a design used as a measure of the impact of a specific change on prevailing norms or assumptions (Pedersen et al., 2016). The causal effect arises when variation in one variable (phenomenon) in this case an independent variable, causes, on average, variation in another variable, known as dependent variable (Pedersen et al., 2016). According to Griffin et al., (2012), this design is used because it focuses on an analysis of a specific problem or situation to give an explanation of the patterns of relationships between the variables. It is also important in identifying the reasons for certain norm or process. Besides that it may be used for duplication where necessary. In addition, this design produces higher internal validity levels as a result of selecting subjects systematically.

\section{Population}

Target population has been defined by Korb (2012) as the group of people that the researcher is planning to make a conclusion about at the end of the study. Polit and Hungler (1999) define population as the total or an aggregate of all subjects, objects or members whose description or characteristics is similar to those specified. In the current study, the target population was all multinational companies in Kenya. Due to lack of a comprehensive data base of multinational companies the study was not able to identify the exact number of MNCs in the country. The study looked at the trend in financial performance of these companies for fifteen years from 2002 to 2017 . This period was selected because the Kenyan economy has undergone diverse changes over the past two decades and this had eventually affected the companies in Kenya both local and international. The research looked at the financial reports of these multinational companies.

\section{Sampling frame}

This refers to the procedure or list of identifying all elements in a target population (Bloomberg, 2012). It is a list containing all the elements in a population. This study used simple random sampling method by picking data of four multinational companies over a period of the last 15 years from 2002 to 2017 for the variables being studied in order to meet the study objectives. The multinational companies under study were found in Kenya. The study chose to focus on four of the largest MNCs which included Barclays Bank, Standard Charted Bank, Total and British American Tobacco.

\section{Data collection procedure}

The research utilized secondary method of data collection through review of existing records. Secondary method of data collection was used because it enabled the access of large data volumes collected and stored or archived by various researchers all over the world and also using the existing data is becoming more relevant in the present world (Smith, 2008). According to Tran Thi Ut (2013), secondary method was relevant because it helped extract the exact information needed from other sources (secondary sources). It also gave facts about the performance of the companies, thus provided descriptive information about the situation. This method was also good in model building whereby the information specified the relationship between variables, whether two or more. This method was also useful since it allowed data mining through exploration of data over large volumes of data in order to discover the trend about the organizations' customer behavior, products, sales and profitability. This method was used because it did allowed for study of dynamics of the situation, frequency counts of the targeted behaviors or any other changes as indicated by the evaluation needs. It was also used because it provided good source additional information about the different groups. This method also produced quantitative (such as counts, instructional time, frequency and mean length of interactions) and qualitative (such as narrative data). The method of data collection was observation of documents and record. This involved the observation of financial statements and reports of the selected multinational Companies. This involved an analysis of their financial reports of 15 years between 2002 and 2017. An analysis of ratios of profitability which include return on assets and return on equity was done and a conclusion on profitability done afterwards. The 15 years were split into three segments each consisting of 5 years where this analysis was done. Data for balance of payment was obtained from IMF, World bank and Central Bank of Kenya, for government debt was obtained from Kenya National Bureau of statistics (KNBS), data for terms of trade was obtained from the Federal Reserve Bank and National Accounts at a glance book, data for inflation rate was obtained from World bank, World Data Atlas and Kenya National was obtained from selected Kenyan MNCs' financial statements.

\section{Data Processing and analysis}

In order to find out the effect of the determinants of exchange rates on financial performance of selected MNCs in Kenya the study used the model employed by Saeedi and Mahmoodi (2011) which is presented in equation 3.1.

$$
Y=\beta_{0}+\beta_{1} X_{1}+\beta_{2} X_{2}+\beta_{3} X_{3}+\beta_{4} X_{4}+\varepsilon \ldots
$$

Where

$Y$ Denotes the dependent variable, financial performance $\beta_{0}$ Denotes the constant term 
$\beta_{1}-\beta_{4}$ Denotes the coefficients to be estimated

$X_{1}$ Denotes the balance of payments

$X_{2}$ Denotes the inflation rate

$X_{3}$ Denotes the terms of trade

$X_{4}$ Denotes the level of debt

$\varepsilon$ Denotes the error term

The study utilized the linear regression model to determine the relationship between the independent and the dependent variables. The data was cross-sectional as well as time series. Greene (2012) indicates that data with such dimensions should be estimated using the linear panel regression approach. The data was estimated using STATA software.

\section{Diagnostic Test}

According to Porter and Gujarati (2009), it is critical for the study data not to violate the assumptions of the classical linear regression model (CLRM). Estimation of equation 3.1. When the assumptions are violated the results will be spurious, biased, not consistent and not efficient. The study also performed the auto-correlation, multicollinearity, heteroscedasticity as well as panel unit root tests.

\section{Multicollinearity}

Multicollinearity tests are normally conducted to test the relationship between variables under study. The test evaluates if the variables under study determine each other or move in the same direction (Gujarati \& Porter, 2009). Multicollinearity is tested using a matrix called correlation matrix where the cut-off level is 0.8 (Greene, 2012). If the results give correlation coefficient exceeding 0.8 , it shows that multicollinearity level is high amongst the variables. Greene (2012) suggests that the remedy for this is to remove one of the variables.

\section{Heteroscedasticity}

The assumptions of the CLRM require the error term variance to be persistent and not changing for all variables (Parker, 2016). This is what is commonly referred to as homoscedasticity. Research by Prabhakaran (2016) showed that cross-sectional data often suffer from heteroscedasticity. The presence of heteroscedasticity results in estimates that are inefficient and return incorrect test statistic results. The Test called Breusch-Pagan was utilized. The null hypothesis states that the error terms are homoscedastic. To correct for heteroscedasticity, the feasible generalized least squares approach is used (FGLS).

\section{Autocorrelation}

Asteriou and Hall (2007) indicate that autocorrelation is the situation that occurs when the covariance and correlation between random error terms are not equal to zero. This violation is typically seen in time series data. To check for autocorrelation the Wooldridge Test was used. The existence of auto-correlation in data is corrected for by use of FGLS.

\section{Panel Unit Root Test}

This test was done to check stationarity of study data (Greene, 2012). Data is stationary when variances as well as mean are constant over time. Additionally, the co-variance between two periods relies on the range or gap between the two periods of time but not the exact time when the covariance is calculated (Gujarati \& Porter, 2009). Non-stationarity of study data results in spurious results. The Augmented Dickey Fuller (ADF) test was utilized to determine the data stationarity. When data is not stationary it is differenced.

\section{Research Findings and Discussions}

\section{Table 4.1: Descriptive Statistics}

\begin{tabular}{|c|c|c|c|c|c|}
\hline Variable & Observations & Mean & Std. Der. & Vin & .l.ax \\
\hline ROA & 256 & 0.0222 & 0.047 & -0.0015 & 0.3337 \\
\hline ROE & 256 & 0.1404 & 0.3237 & 0.0226 & 2.4999 \\
\hline $\mathrm{BOP}$ & 64 & .0328429 & 0.1141566 & -0.2754 & 0.3078 \\
\hline INELATION & 64 & 9.6402 & 5.4044 & 1.9613 & 26.2398 \\
\hline TERMS OF TRADE & 64 & -0.4121 & 0.3769 & -1.3364 & 0.02068 \\
\hline DEBT & 64 & 0.1238 & 0.0181 & 0.9968 & 0.1571 \\
\hline
\end{tabular}

As shown in Table 4.1 the value of mean of Return on Assets with 256 observations was 0.0292 . The standard deviation was 0.0487 a minimum of -0.0015 and a maximum of 0.3337 . The positive ROA indicates that on average the multinationals were profitable during the period 2002-2017. The negative minimum value shows that during the period some firms had recorded losses. The ROE's mean was 0.1404 , its standard deviation was 0.3237 , minimum value was 0.0226 and maximum 2.4999 indicating that the shareholders were receiving positive returns.

The mean of the BOP was -0.3284 , standard deviation was 0.1142 minimum value was -0.2754 , maximum value was 03078 for 64 observations. This implies that on average the company imports more goods, services, and capital than it exports. The country is a net consumer not a net producer of the output produced by outside countries. The positive BOP implies that in some years the country was a net producer. The inflation rate during the period 2002-2017 averaged $9.64 \%$, standard deviation was 2.4567 , and minimum inflation rate was $1.9613 \%$ with a maximum of $26.2398 \%$. The mean of $9.64 \%$ indicates that inflation was significantly above Central Banks target which is $\pm 5 \%$. The mean for public debt as percentage of GDP was 0.1238 with standard deviation of 0.0181 for 64 observations. The maximum value was 0.9968 implying that the level of debt is significantly high.

\section{Diagnostic Tests}

The researcher conducted diagnostic tests in order to prove that no single assumption of classical linear regression model (CLRM) was violated and also to ensure that the correct analysis model was chosen just in case the assumptions of CLRM were violated. 
Multicollinearity Test Result

Table 4.: Results of the Julticollinearity Test

\begin{tabular}{lllllll} 
Variables & ROA & ROE & BOP & TOT & NFLATION DEBT \\
\hline ROA & 1.000 & & & & & \\
ROE & .0 .1988 & 1.0000 & & & \\
BOP & .0 .1518 & 0.1478 & 1.000 & & & \\
TOT & 0.1328 & .0 .0508 & 0.1075 & 1.000 & & \\
NELATIOS & 0.0129 & -0.4939 & 0.0442 & 0.4195 & 1.0000 & \\
DEBT & 0.1112 & 0.462 & 0.0499 & 0.2462 & .0 .1908 & 1.0000 \\
\hline
\end{tabular}

The results presented in Table 4.2 show that the correlation coefficients of each of the variables are less than 0.8 . This shows that there is no severe correlation. The study data does not suffer from multicollinearity.

\section{Autocorrelation}

The Wooldridge test was done to establish whether or not there was autocorrelation in the study data. The results are as shown in Table 4.3 and Table 4.4 for the ROA and ROE respectively.

Table 4.3: Results of the Autocorrelation Test for ROA

$\mathrm{F}(1, \quad 3)=381.581$
Prob $>\mathrm{F}=0.0003$

\section{Source: Study Data (2019)}

The null hypothesis for the Wooldridge test states the firstorder autocorrelation was not in the data. The F statistic reported for this test statistic. The computed $\mathrm{F}$ test was 1 with 3 degrees of freedom for the ROA. The p-value for the F test was 0.0003 . This is less than the critical value 0.05 . This suggests that the equation with ROA suffers from autocorrelation.

Table 4.4: Results of Autocorrelation Test for ROE

\begin{tabular}{c}
$\mathrm{F}(1, \quad 3)=5.398 \mathrm{e}+07$ \\
\hline Prob $>\mathrm{F}=0.0000$
\end{tabular}

\section{Source: Study Data (2019)}

The results of Table 4.4 reveal that $F$ test was 1 with 3 degrees of freedom for ROE. The p-value was 0.0000 , this was less than 0.05 this suggest that the ROE equation had autocorrelation problems. CLRM assumptions were violated simply because there was autocorrelation. To solve this problem the study used Feasible Generalized Least Squares (FGLS).

\section{Heteroskedasticity Results}

The study evaluated the data for panel-level heteroscedasticity by the help of the Breusch-Pagan Test. The results are as shown in Table 4.5 and 4.6.
Table 4.5: Heteroskedasticity Test Results for ROA

\section{Breusch-Pagan/Cook-Weisberg test for heteroscedasticity}

Ho: Constant variance

Variables: fitted values of ROA

$\operatorname{chi} 2(1)=26.39$

Prob $>$ chi2 $=0.0000$

Source: Study Data (2019)

Table 4.6: Heteroskedasticity Test Results for

ROE

\section{Breusch-Pagan / Cook-Weisberg test for} heteroscedasticity

Ho: Constant variance

Variables: fitted values of ROE

$\operatorname{chi} 2(1)=18.59$

Prob $>$ chi $2=0.0000$

\section{Source: Study Data (2019)}

The null hypothesis for this test is constant variance which implies that the data is homoscedastic. The Chi-square value is 26.39 for ROA with probability 0.000. Given that the probability is less than $5 \%$ critical value suggests the rejection of the null hypothesis. The data is not homoscedastic. The chisquare for ROE is 18.59 as depicted in Table 4.6. The associated p-value is 0.0000 indicating the presence of heteroscedasticity. Both the ROA and ROE equations violate the CLRM assumptions. To solve this problem the study data will be estimated using FGLS.

\section{Panel Unit Root Test}

The panel unit root test was conducted in order to avoid spurious results. The study used Augmented Dickey Fuller (ADF) Test. The null hypothesis for the ADF test states that the data has unit root test.

\section{Table 4.7: Results of Augmented Dickey Fuller} Test for ROA

\begin{tabular}{lcccc}
\hline & Test & Statistic & p-value \\
\hline Inverse chi-squared (80) & $\mathrm{P}$ & 0.3423 & 0.0000 \\
\hline Inverse normal & $\mathrm{Z}$ & 0.0051 & 0.0000 \\
\hline Inverse Logit t (189) & $\mathrm{L}^{*}$ & 0.0012 & 0.0000 \\
\hline Modified inv. chi-squared & Pm & 0.0204 & 0.0000 \\
\hline Number of Panels 62 & Avg. number of periods $=4.13$ \\
\hline Source Study Data (2019)
\end{tabular}

The results indicated in Table 4.7 reveal that $p$-value for all the test statistics are less than 0.05 critical value. This means that 
"Effects of Exchange Rate Determinants on Financial Performance of Multinational Companies"

null hypothesis is not accepted. Table 4.8 indicates the outcome of ADF test for ROE.

Table 4.8: Results of Augmented Dickey Fuller Test For ROE

\begin{tabular}{lccc} 
& Test & Statistic & p-value \\
\hline Inverse chi-squared (80) & $\mathrm{P}$ & 0.00493 & 0.0001 \\
\hline Inverse normal & $\mathrm{Z}$ & -0.0071 & 0.0088 \\
\hline Inverse Logit t (189) & $\mathrm{L}^{*}$ & -0.0017 & 0.0009 \\
\hline Modified inv. chi-squared & $\mathrm{Pm}$ & 0.0377 & 0.0000 \\
\hline
\end{tabular}

Number of Panels 62 Avg. number of periods $=4.13$ Source: Study Data (2019)

The results presented in Table 4.8 show that the p-values are less than the critical value of 0.05 . The null hypothesis is not accepted.

Table 4.9: Results of Augmented Dickey Fuller for BOP

\begin{tabular}{llll}
\hline $\begin{array}{l}\text { Augmented Dickey- } \\
\text { Fuller test for unit root }\end{array}$ & \multicolumn{2}{l}{ Number of obs $=$} & 32 \\
\hline & $1 \%$ & $5 \%$ & $10 \%$ \\
Test & Critical & Critical & Critical \\
\hline & & & \\
Statistic & Value & Value & Value \\
\hline
\end{tabular}

\begin{tabular}{llll}
$\mathrm{Z}(\mathrm{t})$ & -4.316 & -3.572 & -3.223 \\
\hline
\end{tabular}

Mac kinnon approximated p-value for $Z(t)=1.0000$ Source: Study Data (2019)

The outcomes summarized in Table 4.9 depict that constant and time trend computed using a sample of 32 observations yields $\gamma$ statistic of -3.572 . This is much lower than the-3.50\% critical value, thus at $95 \%$ critical value the null hypothesis of a unit root is rejected.

Table 4.10: Results of Augmented Dickey Fuller Test for Terms of Trade

\begin{tabular}{llll}
\hline $\begin{array}{l}\text { Augmented Dickey- } \\
\text { Fuller test for unit root }\end{array}$ & \multicolumn{2}{l}{ Number of obs $=$} \\
\hline & $1 \%$ & $5 \%$ & $10 \%$ \\
Test & Critical & Critical & Critical \\
\hline Statistic & Value & Value & Value \\
\hline$Z(\mathrm{t})$ & -4.932 & -4.572 & -3.321 \\
\hline
\end{tabular}

Mac kinnon approximate $\mathrm{p}$-value for $\mathrm{Z}(\mathrm{t})=1.0000$ Source: Study Data (2019)

The results shown in Table 4.10 show that the constant and time trend computed using the sample of 32 observations yields a $\gamma$ statistic of -4.572 . This is much lower than the$3.50 \%$ critical value. The null hypothesis is rejected.
Table 4.11: Results of Augmented Dickey Fuller

\begin{tabular}{|c|c|c|c|}
\hline Test for Debt & & & \\
\hline $\begin{array}{l}\text { Augmented } \\
\text { Dickey-Fuller } \\
\text { test for unit root }\end{array}$ & $\begin{array}{l}\text { Number of } \\
\text { obs }=32\end{array}$ & & \\
\hline Test & $\begin{array}{l}\% \\
\text { Critical }\end{array}$ & $5 \%$ Critical & $\begin{array}{l}10 \% \\
\text { Critical }\end{array}$ \\
\hline Statistic & Value & Value & Value \\
\hline $\mathrm{Z}(\mathrm{t})$ & -2.457 & -1.697 & -1.310 \\
\hline $\begin{array}{l}\text { Mac kinnon ap } \\
\text { value for } Z(t) \\
\text { Source: Study D }\end{array}$ & $\begin{array}{l}\text { roximate p- } \\
=1.0000 \\
\text { ta (2019) }\end{array}$ & & \\
\hline
\end{tabular}

The shown summary in Table 4.11 reveals that the constant and time trend computed using a sample of 32 observations yields $\gamma$ statistic of -1.697 . This is much lower than the-3.50\% critical value, thus at $95 \%$ critical value the null hypothesis of the unit root is rejected. Thus the null hypothesis showing all panels with unit root was rejected, thus the data could be estimated at levels (Gujarati \& Porter, 2009).

\section{Hausman Test}

This test was performed to establish whether the random or fixed effect model was relevant for this study. The results are presented in Table 4.12 and 4.13.

Table 4.12: Results of Hausman Test for R0A

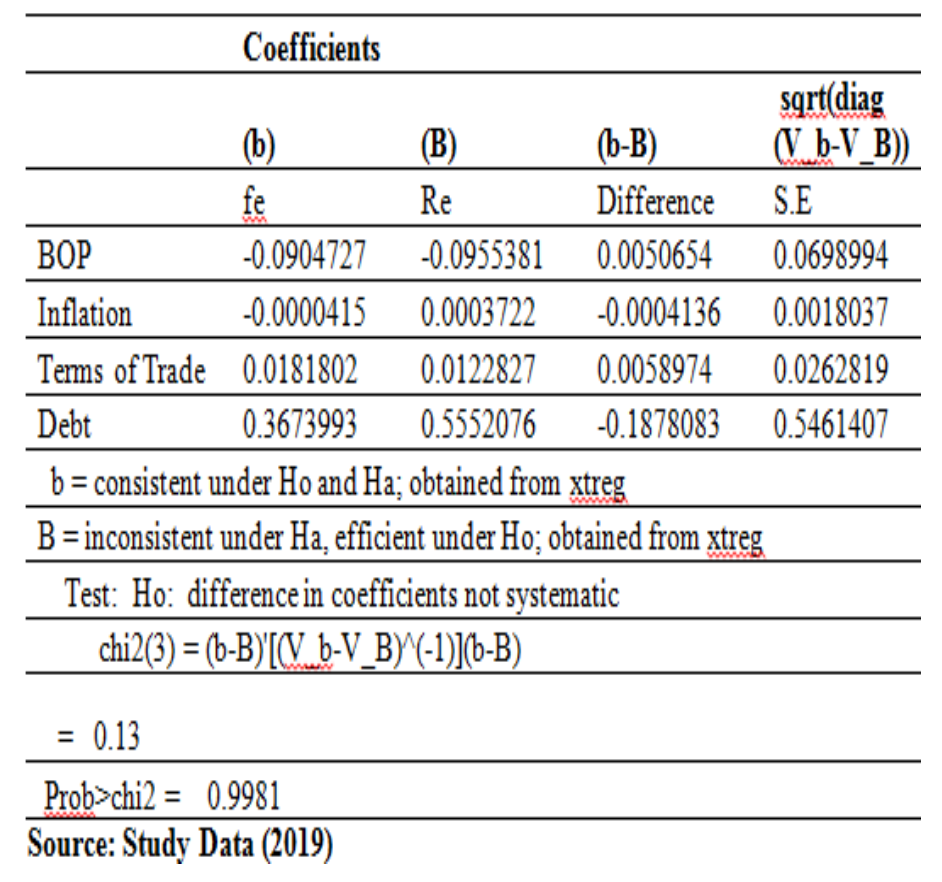

The null hypothesis for the above test states the preference of random effects model to the fixed effects model (Greene, 2012). For the ROA, the chi-square value was 0.12 , p-value was 0.9981 . This means that at $5 \%$ significance level, the value of chi-square was statistically insignificant. Therefore, the null hypothesis was rejected. The ROA model will thus be estimated using the fixed estimation approach. 
Table 4.13: Results of Hausman Test for ROE

\begin{tabular}{llllc}
\hline & Coefficients & & & \\
& (b) & $(\mathrm{B})$ & $(\mathrm{b}-\mathrm{B})$ & $\begin{array}{c}\text { sqrt(diag } \\
(\mathrm{V} \text { b-V_B }) \text { ) }\end{array}$ \\
\hline & $\mathrm{fe}$ & $\operatorname{Re}$ & Difference & S.E \\
\hline BOP & -0.2665872 & -0.2148003 & -0.0517868 & \\
\hline Inflation & -0.0132473 & -0.0174761 & 0.0042289 & \\
\hline Terms of Trade & -0.007981 & 0.052312 & -0.060293 & \\
\hline Debt & 4.360052 & 2.439982 & 1.92007 & 0.8985368 \\
\hline
\end{tabular}

$\mathrm{b}=$ consistent under $\mathrm{Ho}$ and $\mathrm{Ha}$; obtained from xtreg

$\mathrm{B}=$ inconsistent under $\mathrm{Ha}$, efficient under $\mathrm{Ho}$; obtained from xtreg

Test: Ho: difference in coefficients not systematic

$\operatorname{chi2}(3)=(b-B)\left[\left(V_{b} b-V \_B\right)^{\wedge}(-1)\right](b-B)$

$=\quad 3.12$

Prob $>$ chi2 $=0.5377$

Source: Study Data (2019)

For the ROE, the chi-square value was 3.12, p-value was 0.5377 . This means that at $5 \%$ significance level, the value of chi-square was statistically insignificant. Therefore, the null hypothesis was rejected. The ROE model will thus be estimated using the fixed estimation approach.

\section{Inferential Analysis}

\section{Effect of the Determinant of the Exchange Rate on the ROA}

The study set out to determine the effect of the determinants of the exchange rate on financial performance of four multinational companies operating in Kenya. Financial performance in this study was measured using two variables, namely ROA and ROE. The effect of the determinants of the exchange rate on ROA is presented in Table 4.14.

\section{Table 4.14: Results of the FGLS for ROA}

\begin{tabular}{|c|c|c|c|c|c|c|}
\hline \multicolumn{3}{|c|}{ Coefficients: generalized least squarep } & & & & \\
\hline \multicolumn{7}{|c|}{ Panels: homoscedastic } \\
\hline \multicolumn{7}{|c|}{ Correlation: no autocorrelation } \\
\hline Estimated covariances & $=$ & 1 & \multicolumn{4}{|c|}{ Number of obs $=256$} \\
\hline \multicolumn{2}{|c|}{ Estimated autocorrelations $=$} & 0 & \multicolumn{4}{|c|}{ Number of groups $=4$} \\
\hline \multirow[t]{2}{*}{ Estimated coefficients } & $=$ & 5 & Time peri & iods $=($ & $=64$ & \\
\hline & & & Wald chi2 & $2(3)=$ & $=186.19$ & \\
\hline \multicolumn{3}{|l|}{ Log likelihood } & \multicolumn{2}{|c|}{ Prob $>$ chi $=00000$} & 0.0000 & \\
\hline \multicolumn{3}{|l|}{ ROA } & Coef & $\begin{array}{l}\text { Std. } \\
\text { Err. }\end{array}$ & $\mathbf{z}$ & $\mathrm{P}>|\mathbf{z}|$ \\
\hline \multicolumn{3}{|l|}{$\mathrm{BOP}$} & -0.0955 & 0.04089 & $\begin{array}{ll}9 & 2.34 \\
\end{array}$ & 0.0190 \\
\hline \multicolumn{3}{|l|}{ Inflation } & 0.00037 & 0.00083 & 0.45 & 0.6530 \\
\hline \multicolumn{3}{|l|}{ Terms of Trade } & 0.01228 & 0.01224 & 1.00 & 0.3160 \\
\hline \multicolumn{3}{|l|}{ Debt } & 0.55521 & 0.09183 & 6.05 & 0.0000 \\
\hline \multicolumn{3}{|l|}{ cons } & 0.01161 & 0.00267 & 4.35 & 0.0000 \\
\hline
\end{tabular}

Source: Study Data (2019)

Table 4.14 indicate that the balance of payment had a negative but significant impact on ROA as indicated by $\beta=-0.0955$ and p-value 0.0190. These findings contradict the findings of
Klein, Schuh and Triest (2000) who determined that in certain situations the balance of payments movements are fully absorbed by the firm by way of price-cost margins. The findings suggest that the balance of payments movements are not fully absorbed by the price-cost margins and thus reduce the margins of the firms. The findings confirm the results of Hussein and Khan (2014) who established that the deterioration of balance of payments level led to a rise in exchange rate level which impacted the profitability of pharmaceutical firms in Turkey. The cost of imported raw materials needed for the manufacturing process increased while the demand for some of the pharmaceutical products sold internationally reduced owing to the high exchange rate. This served to reduce sales and increase costs which ultimately served to reduce profits. Barasa (2013) establish that the BOP and foreign exchange rate in Kenya are inversely related. The BOP affects firms in the country because the country is a net importer of capital and raw materials. This implies that increases in BOP will reduce the performance of firms which have to pay more due to higher foreign exchange rates. The effect of terms of trade on ROA was found to be positive but statistically insignificant as implied by $\beta=0.01228$ and $\mathrm{p}$ value 0.3160 . This indicates that a unit rise in the terms of trade will result in a 0.01228 rise in ROA but the increase is not statistically significant. These findings contradict the findings of Esen, Ergüzel and Simdi (2016) who established that the levels of international trade (measured by volume of imports and exports) was negatively and significantly related to ROA for firms listed under Istanbul Stock Exchange found in Turkey. These findings suggest that as the ratio of exports to imports increase the level of business activity increases. However, the amount of profits decreases because the firms incur an additional production and marketing costs of entering overseas markets. Additionally, given that Kenya is a net importer, the cost of production increases due to the cost of foreign inputs. The effect of inflation on ROA was found to be positive but statistically insignificant as implied by $\beta=$ 0.00037 , p-value 0.6530 . This implies that a rise in rate of inflation will result in a 0.00037 rise in the ROA. However, the increase will be statistically insignificant. These findings agree with those of Oleka et al. (2015) and Ifeanyi and Chukwuma (2015) that inflation has a very small impact on financial performance. These findings however contradict economic theory which maintains that profitability is inversely related to profitability. Increase in inflation increases production cost which lowers profit margins (Frisch, 1990). Gillman (2013) when explaining demand-pull and cost-push inflation theories indicated that inflation determines prices levels with ultimately affect firm profitability. Gillman (2013) showed that a rise in inflation level raises production level when the economy is operating at full capacity given that there is additional spending and ultimately rising demand for goods and services. The findings of the study suggest that increase in inflation raises demand for services and goods for the 4 multinationals. The effect of debt on the ROA was positive 
and statistically significant as implied by $\beta=0.55521$ and $\mathrm{p}$ value was 0.0000 . The findings imply that increase in one unit of nation's debt level results in a 0.55521 unit increase in the ROA of the MNC sampled in this study. These findings contradict the results of Schweickert and Ahlborn (2015) who found that government debt affects negatively the economic performance. The findings suggest that government debt stimulates the financial performance of entities operating in the economy. Government spends the money it raises from taxes and issuing debt on several avenues ranging from public sector, capital expenditure, welfare, and wages. This expenditure increase business activity in the economy, which rises earning of firms. Typically, there is concern about government borrowing given that it crowds out the private sector receiving lending. The findings of this study however, assuage these concerns. Hofmann (2011) stipulates that there are concerns with government borrowing. However, when managed properly, the credit can be used to stimulate economic activities in the country.

The findings presented in Table 4.14 require that equation 3.1 be written as

$$
Y=0.01161-0.0955 X_{1}+0.5521 X_{4}
$$

\section{Effect of the Determinants of Exchange Rate on ROE}

The study estimated a regression equation to find out the effect of the determinants of exchange rate on ROE. These results are shown in Table 4.15

\section{Table 4.15: Results of the FGLS for ROE}

\section{Coefficients: generalized least squares}

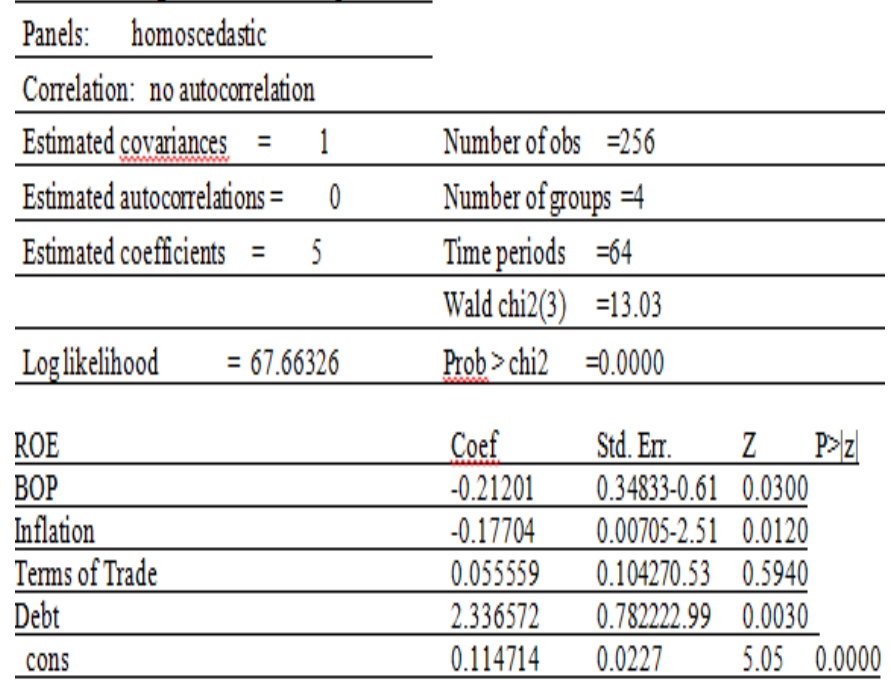

Source: Study Data (2019)

The coefficient of the BOP was found to be -0.21201 , p-value was 0.0300 . This implies that the BOP has a negative and statistically significant impact on ROE of the four MNCs sampled in this study. These disagree with those of Kiganda (2014) that relation between exchange rate determinants and firm's financial performance is insignificant. Mungami (2012) found that the balance of payment was an important factor that determined the exchange rate in Kenya which determined the competitiveness of firms. The economy liberalization had improved exchange rate but did not lead to improvement in current account or reduction of the deficit of balance of trade. The study sample included firms in the financial and manufacturing sector, the present situation of the current account and the present balance of trade deficit were hampering the performance of the firms. The effect of inflation was negative and statistically significant as shown by $\beta=-0.017704, \mathrm{p}$-value was 0.0120 . The findings imply that a unit rise in inflation level result in 0.0177045 unit fall in the ROE. These findings confirm the findings of Oleka et al. (2015) that increase in inflation resulted in an erosion of the earnings realized by firms. Inflation reduces the level of cash flow generated by the firms, in order for the firms to have adequate funds to pay their shareholders returns; they need to generate earnings that are above the inflation rate. This can be done by passing on the full inflation costs to the consumers. However, this will have the result of reducing demand. These findings are consistent with macroeconomic theories that suggest that increase in inflation results in a decrease in earnings which affects negatively the returns to the shareholders. The effect of terms of trade on ROE was found to be positive but statistically insignificant as implied by $\beta=$ 0.0559 and $\mathrm{p}$-value 0.5940 .This indicates that a unit rise in the terms of trade will result in 0.0559 fall in ROE but the increase is not statistically significant. These findings contradict the findings of Esen, Ergüzel and Simdi (2016) who established that the levels of international trade (measured by volume of imports and exports) was negatively and significantly related to shareholders equity for firms listed under Istanbul Stock Exchange in Turkey. As Kenya is a net importer, the cost of importing foreign goods serves to reduce the earnings of the firms. The effect of debt on the ROE was positive and statistically significant as depicted by a coefficient of 2.3366 and probability of 0.0030 . The findings imply that a unit rise in the debt of the public causes 2.3366 unit rise in the ROE. These findings contradict the findings of studies done locally. Various academics have found that in Kenya, government debt leads to decline in the performance of firms (Kangara, 2015; Ngugi, 2016; Mukambi et al., 2017). These findings confirm the findings of Shijaku (2013) and Mencinger et al., (2014) that increase in debt levels causes increase in the productivity of the economy hence increased returns on amounts invested. Unlike local studies, Shijaku (2013) looked at the supply and demand factors relating to public borrowing. The study revealed the government debt related positively to growth of the economy. This growth makes other sectors of the economy to grow also. The findings suggest that the fiscal policy approach of the government has positive effect on returns and earnings to firm owners. The arguments that government debt crowds out private sector credit which in turn results in decrease in margins seems not to apply in the case of the four MNCs sampled in this study. The findings suggest that government borrowing has multiplier effects.

According to the results shown in Table 4.11 equation 3.1 can be written as 
$Y=0.1147-0.21201 X_{1}-0.1770 X_{2}+2.3366 \beta_{4} \ldots \ldots .4 .2$

\section{Summary of findings}

Using the FGLS estimation approach, the study established a positive and statistically significant relationship between BOP and the ROA and ROE.Inflation had a positive and statistically insignificant effect on ROA. It also revealed that inflation had a negative and statistically significant effect on ROE.The terms of trade was computed as a ratio of total exports value to total imports value. The study found that terms of trade had positive but statistically insignificant impact on ROA and ROE.The government debt was computed as total debt ratio to the gross domestic product (GDP). It was established that debt of the government had a positive and significant effect on ROA and ROE.

\section{Conclusions}

The study made a conclusion that an increase in the balance of payments has a significant negative effect on financial performance of selected MNCs sampled in the study. The findings showed that postulations put forward in the international trade theory of movements in the balance of payments and their effects of returns hold in Kenya. The study established that increases in the level of inflation have an insignificant effect on the ROA. The return on assets was computed as net profits ratio to total assets. This suggests that Ricardo argument that dis-equilibrium associated with price increases does not affect the equilibrium holds with regard to ROA. The study established that increases in inflation result in decreases in ROE. The return on equity was computed when net profits were divided by the shareholders' equity. The study concluded that shocks to inflation affect firm performance through changes in the amount earned as return by the shareholders. The study concluded that the terms of trade had positive but insignificant effect on performance of the firms sampled in the study. A conclusion was thus made that the level of imports or exports did not affect the factors that determine the profitability of the MNCs. The study found that increases in public debt results in increases in the financial performance of the MNCs sampled by the study. A conclusion was thus made that public borrowing had a multiplier effect on performance of MNCS.

\section{Recommendations}

The balance of payment accounts significantly for the performance of multinational firms in Kenya. The levels of current account deficit affects exchange rate which determines performance of firms operating in the economy. Given that the county is a net importer of capital and raw materials the exchange rate rise causes a rise in cost of business as firms have to acquire capital and raw materials at higher prices. This makes the balance of payment important to develop a country since it affects the costs of doing business. The cost of doing business affects the level of employment and development of firms. The findings of the study imply that the government should manage the balance of payment more aggressively. If the balance of payments improves, it would stimulate firms to expand business and create employment as the cost of doing business will decrease. Additionally, the price of Kenya products will become more competitive in the international markets.

The organization's financial performance can be measured by different indicators such as Return on Investment (ROI), Return on Assets (ROA), Return on Equity (ROE) and Return on Capital Employed (ROCE). The study elected to adopt ROE and ROA as the information needed to compute this indicators was easily available. The study results suggested that inflation had a positive but statistically small effect on ROA and negative and statistically significant effect on ROE. Given that negative effects are statistically significant; this study recommends the Central Bank to formulate more comprehensive policies which will reduce inflation level. Additionally, firms need to come up with better strategies to mitigate inflation effects on earnings.

The results also indicate that the terms of trade do not, to a large extent affect the Kenyan MNCs financial performance. Given that the effects are not statistically significant it's recommended by the study that policymakers in government should focus more on other factors rather than on the terms of trade.

Government debt had a positive significant effect on multinationals' financial performance. This implies that government borrowing leads to positive multiplier effects for businesses. The study recommends that the government should continue to borrow as this debt results in increase in earnings in the private sector. Policymakers should not be too concerned with the crowding out effect of government borrowings.

\section{Suggestions for Further Research}

It is suggested by the study that future studies should include more macro-economic variables including interest and money supply. Future studies should also focus on the MNCs hedging strategies against movements in the exchange rate determinants and how the hedging strategies affect performance. Some of the relationships hypothesized in the study were found to be statistically insignificant. Additionally, unit variations in predictor variables explained only a small portion of variations in the dependent variables. Further studies should include control variables that are specific to MNCs. Additionally, the variables should be lagged so that changes for different times may be accounted for. The study only focused on four multinational companies. To allow for the generalization of the findings, there needs to be more elaborate study that includes as many multinational firms in Kenya. For such a study, there needs to be a comprehensive list of all the multinationals operating within Kenya. Further, the research should include quantitative and qualitative data. 


\section{References}

1. Ahlborn, M. \& Schweickert, R. (2015). Public Debt and Economic Growth - Economic Systems Matter. Forschungspapiere Research Papers, 2015(2), 132. doi:PFH.FOR.278.1512.

2. Ahmad, N. et. al., (2014). Impact of Exchange Rate on Balance of Payment: An Investigation from

Pakistan. U.S. Research Journal of Finance and Accounting.

3. Ali, G. (2010). Pakistan's Balance of Payments as a Monetary

4. Al-Rodhan, N.R.F. (2006) Definitions of Globalization: A Comprehensive Overview and a Proposed Definition. Switzerland: Geneva Centre for Security Policy Approach. Working paper no.01/04) Fiji: Reserve bank of Fiji.

5. Arkolakis, C. et. al. (2014). Universal Gravity. Cambridge: National Bureau of Economic Research.

6. Aspromourgos, T., Rees, D. and G. White (2010). Public Debt Sustainability and Alternative Theories of Interest. Cambridge Journal of Economics.

7. Asteriou, D., \& Hall, S. (2007). Applied econometrics: A modern approach using Eviews and Microfit Revised Edition. Boston: Palgrave Mcmillan.

8. Augustin Kwasi FOSU, A. K. (2011). Terms of Trade and Growth of Resource Economies: A Tale of Two Countries. (Centre for the study of African Economies No. 09). Oxford: University of Oxford.

9. Balance of Payments Manual, 5th Ed.(1993) International Monetary Fund, Washington D.C.:USA.

10. Barasa, B. (2013). The relationship between exchange rate volatility and balance of payments in

11. Bartov, E. and Bodnar, G.M. (1994). Firm Valuation, Earnings Expectations, and the Exchange-Rate Exposure EffectBingley: Emerald Group Publishing.

12. Berberoğlu, M (2017). Relationship Between Foreign Trade and Financial Performance of Companies.

13. Bergen, J.V. Factors That Influence Exchange Rates.

14. http://www.investopedia.com/articles/basics/04/0507 04.asp

15. Bhattacharjea, A. and Marjit, S. (2004). Globalization and the Developing Economies: Theory and

Evidence. New Delhi: Manohar. Blackwell PublishingLtd.

16. Blecker, A \& Ibarra, C. (2012). Trade liberalization and the balance of payments constraint with intermediate imports: The case of Mexico revisited. Journal of Structural Change and Economic Dynamics, 25(2013), 33-47. Retrieved from http://isiarticles.com/bundles/Article/pre/pdf/79534.p df

17. Bloomberg, J. H. \& Sonenstein, F. (2012). Issues in Survey Research Design. Retrieved from:
http://ocw.jhsph.edu/courses/SurveyResearchDesign.

18. BS Reporter, (2016).Indian FMCG firms outpace MNCs in growth, revenue. Mumbai.

19. Campbell, D. \& Campbell, S. (2008). Introduction to Regression and Data Analysis. (Statlab Workshop 2008) New Haven: Yale University.

20. Campbell, S., \& Campbell, D. (2008). Statlab Workshop: Introduction to Regression and Data Analysis.

21. Checherita, C. \& Rother, P. (2010). An Empirical Investigation for the Euro Area (European Central Bank No.1237). Frankfurt: European Central Bank.

22. Cliff, O. \& Ogeto Willy, O. (2014). MacroEconomic Fluctuations Effects on the Financial Performance of Listed Manufacturing Firms in Kenya. The International Journal of Social Sciences, 21(1), 2640. Retrieved from: www.TIJoss.com

23. Commercial Banks in Kenya. International Journal of Academic Research in Accounting, Finance and Management Sciences, 6(2), 121-133. Retrieved from: www.hrmars.com

24. Davis, J.L. S. and Darity W. (2005).Growth, trade and uneven development. Cambridge Journal of Economics. New York: Oxford University Press.

25. Deardorff, A. V. (2016). What Do We (and Others) Mean by "The Terms of Trade"? University of Michigan: Michigan.

26. Dhasmana, A. (2014). Macroeconomic Policy: How exchange rate changes impact Indian manufacturing firms. Bangalore: Indian Institute of Management.

27. Dunning, J. H. and Lunda, S. (2008). Multinational enterprises and the global economy. Northampton: Edward Elgar Publishing.

28. Eun, C. S. \& Resnick, B.G. (2014). International Financial Management. Europe: McGraw- Hill Education.

29. European Central Bank. Evidence from Turkey. Prague Economic Papers. Prague: University of Economics.

30. Flota, C. (2014). The Impact of Exchange Rate Movements on Firm Value in Emerging Markets: The Case of Mexico. Mexico: Scientific \& Academic Publishing.

31. Folster, S \& Henrekson M, (2001). Growth effects of government expenditure and taxation in rich countries. European economic Review. 45(8) 224233.

32. Frisch, H. (1990). Inflation: definition and measurement. In Theories of Inflation $\left(2^{\text {nd }}\right.$ ed., pp. 1029). Cambridge: Cambridge University Press.

33. Froot, K.A. (1990). Multinational Corporations, Exchange Rates, and Direct Investment: In International Policy Coordination and Exchange Rate Fluctuations'. Chicago: University of Chicago Press. 
"Effects of Exchange Rate Determinants on Financial Performance of Multinational Companies"

34. Graham, J, Leary, T. M. \&Roberts, M.R. (2014).How Does Government Borrowing Affect Corporate Financing and Investment? (National Bureau of Economic Research Working Paper No. 20581). Cambridge: National Bureau of Economic Research.

35. Greene, W. (2012). Econometric Analysis ( $7^{\text {th }}$ ed.). New York: Pearson.

36. Griffin, M. et al. (2012) "Business Research Methods: with Qualtrics Printed Access Card" Boston: Cengage Learning.

37. Growth Empirical Evidence from Kenya using Causality Test Approach. Journal of Advances in Management \& Applied Economics, 1(3), 153-196. Retrieved from: http://www.scienpress.com

38. Gujarati, D. \& Porter, C. (2009). Basic econometrics $\left(5^{\text {th }} e\right.$ d.). Boston: McGraw-Hill

39. Gwartney, J. et al. (2012). 2012 Economic Freedom Dataset, published in Economic Freedom of the World: 2012 Annual Report. British Columbia: Fraser Institute.

40. Harper J. and Aggarawal R. (2010). Foreign exchange exposure of "domestic"corporation. Amsterdam: Elsevier.

41. Hartogh, M. (2007). The real thing: a profile of the coca cola company. California

42. Helhel.Y (2015). Foreign Exchange Rate Exposure and Its Determinants on Performance of Manufacturing Firms in Turkey. Antalya

43. http://www.econ.ku.dk/jrm/PDFfiles/Munch\%20Scha ur\%20November\%202016.pdf

44. https://www.econlib.org/library/Enc/BalanceofPayme nts.html

45. Hussain, N., \& Khan, A. (2014). An Analysis of the Stock Return and Exchange Rate Variation on Market Return of Pharmaceutical Industry in Pakistan. World Applied Sciences Journal, 31 (6), 1180-1187.

46. Hussein, S. \& Dewan, W (2001). Determinants of Economic Growth-Panel Data

47. Ians, G. (2016). Highest profit after tax margin is maintained at $25.48 \%$. New Delhi

48. Ifeanyi, N \& Chukwuma, C (2016). An Empirical Analysis of Inflationary Impacts on Profitability and Value of Selected Manufacturing Firms in Nigeria. Research Journal of Finance and Accounting 7(12), 22-23. Retrieved from:

http://iiste.org/Journals/index.php/RJFA/article/view File/31508/32348

49. Ifeanyi, N. \& Chukwuma, U. (2016). An Empirical Analysis of Inflationary Impacts on Profitability and Value of Selected Manufacturing Firms in Nigeria. Research Journal of Finance and Accounting, 7(12), 19-26. Retrieved from: www.iiste.org

50. İlhan, H. (2016).Foreign Exchange Risk and Financial Performance: The Case of Turkey.
51. International Journal of Management Economics \& Business, suppl. (13), 36-42 Retrieved from: http://dx.doi.org/10.17130/ijmeb.2017ICMEB173542 0

52. International Journal of Social Sciences and Project Planning Management.

53. Isaya Maana, I., Owino, R. \& Mutai, N. (2008, July $9^{\text {th }}$ to 11 th). Domestic Debt and its Impact on the Economy - The Case of Kenya. Paper Presented During the 13th Annual African Econometric Society Conference, Pretoria, South Africa. Pretoria: Econometric Society Africa Region.

54. Iyoboyi, M \& Muftau, O. (2014). Impact of exchange rate depreciation on the balance of payments: Empirical evidence from Nigeria. Journal of Cogent Economics \& Finance. United

Kingdom:Cogent OA

55. Jakob R. Munch, J. R. \& Schaur, G. (2016). The Effect of Export Promotion on Firm-Level Performance. Journal of Economic Literature. (JEL: F13, F14, H32)

56. Jensen, M. (2001), "The modern industrial revolution, exit and the failure of internal control systems". Journal of Finance, Vol.4 No.3,pp.831-80.

57. Jong, A \& Roell A.A (2006). The financing of Dutch firms: A historical perspective. Amsterdam: Elsevier.

58. Kenya (unpublished master's thesis). University of Nairobi, Kenya.

59. Kiganda, E. O. (2014). Effect of macroeconomic factors on commercial banks profitability in Kenya: Case of equity bank limited. Journal of Economics and Sustainable Development, 5(2), 2222-1700.

60. Klein, M., Schuh, S., \& Triest, R. (2002). Job creation, job destruction, and the real exchange. Journal of Economics, 59(2), 239-265.

61. Konstantin, M. W., Philipp, G. \& Tabea, L. (2014). Terms of Trade, Foreign Direct Investment, and

Development: A Case of Intra-Asian "Kicking Away the Ladder"? (Asian Development Bank Working Paper Series No. 122). Asian Development Bank: Metro Manila.

62. Korb, K.A. (2012). Conducting Educational Research: Identify the population. Retrieved from: http://korbedpsych.com/R05Population.html

63. Korsby, C. and Enevoldsen. (2014). Exploring the Exchange Rate Exposure Puzzle: A cross- country analysis of 60 multinational firms in the period 20052012. Aarhus University.

64. Krishnamurti, C. \& Alssayah, A. (2013). Theoretical Framework of Foreign Exchange Exposure, Competition and the Market Value of Domestic Corporations. Turkey: The Social Sciences Research Society.

65. Levi, M. D. (2009). International Finance. Columbia: Routledge. 
66. Levy, S. (2010). International Trade Theory and Policy: A Review of the Literature. Economics Institute of Bard College.

67. Live Mint. (2016). The steady rise of MNCs.

68. Maigua, C. \& Mouni, G. (2016). Influence of Interest Rates Determinants on the Performance of multinationals.

69. Matiti, C. (2013). The relationship between public debt and economic growth in Kenya.

70. Mencinger, J., Aristovnik, A. \& Verbič, M.(2014). The Impact of Growing Public Debt on Economic Growth in the European Union.Amfiteatru Economics, 35.16(2014), 403-414.Retrieved from:

71. https://mpra.ub.unimuenchen.de/53243/1/MPRA_paper_53243.pdf

72. Mirabelle Muûls, M. \& Pisu, M. (2007).Imports and exports at the level of the firm: evidence from Belgium, (LSE Research Online Documents on Economics No.19711). London School of Economics and Political Science: LSE Library.

73. Morgan, R. \&Katsikeas, C (1997) "Theories of international trade, foreign direct investment and firm internationalization: a critique", Management Decision, Vol. 35 Issue: 1, pp.68-78, Retrieved from: https://doi.org/10.1108/00251749710160214

74. Muller, A. \& Verschoor, W. (2006). European Foreign Exchange Risk Exposure. Oxford:

75. Murtuza, H. (2016). MNCs witness sharp fall in profit growth. New Age

76. Noor, C. \& Abdalla, A. (2014). The Impact of Financial Risks on the Firms' Performance: European Journal of Business and Management.

77. O'Keeffe, D. \& Allen, J. (2012). Global Growth: Where to play and how to win in developing markets.

78. Odili, O. (2014). Exchange Rate and Balance of Payment: An Autoregressive Distributed Lag (Ardl) Econometric Investigation on Nigeria. Journal of Economics and Finance,4(6), 21-30. Retrieved from http://www.iosrjournals.org/iosr-jef/papers/ vol4-issue6/ C0462120.pdf

79. Oleka, C. D., Eyisi Adanma Sabina, E. A. \& Ebue, M.I. (2015). Relationship between Inflation and Firms' Performance-Evidence from Nigeria. World Applied Sciences Journal,33(5), 814-822. doi: 10.5829/idosi.wasj.2015.33.05.14584

80. Olufem, A. T. (2010). Exchange Rate Risk Exposure of Nigerian Listed Firms: An Empirical Examination. Nigeria.

81. Otuori, O. H. (2013). Influence of exchange rate determinants on the performance of commercial banks in Kenya. European Journal of Management Sciences and Economics. UK: Mary \& Sam Research Academia.

82. Ozturk, I. et.al., (2015). Investigating Exchange Rate Exposure of Energy Firms:
83. Parker, J. (2016). Section 8: Heteroskedasticity. Retrieved from; www.reed.edu/economics/parker/ s11/312/notes/Notes8.pdf

84. Patjoshi, P.K. (2013). The Effect of Inflation on Measures of Financial Performance on Indian Manufacturing Industry. Asian Journal of Management, 4(1), 28-35. Retrieved from: http://www.i-scholar.in

85. Paul R. Krugman, P. and Smith, A. (1994).Empirical Studies of Strategic Trade Policy. Illinoi: University of Chicago Press.

86. Phenomenon: (Econometric Evidence).Journal of Managerial Sciences, 5(2),167-176. Retrieved from:http://www.qurtuba.edu.pk/jms/default_files/JM S/5_2/JMS_July_December2011_167-178.pdf

87. Piana, V. (2001). Exchange rate. Rome: Economics web institute.

88. Polit, D. F. \& Hungler, B.P. (1999). Nursing Research: Principles and Methods. Philadelphia: Lippincott.

89. Popper, A. \& Parsley, D. C. (2006). Exchange rate pegs and foreign exchange exposure in East and South East Asia. Pergamon: Pergamon.

90. Prabhakaran, S. (2016). How to detect heteroscedasticity and how to rectify it. Data science +. Retrieved from https://datascienceplus.com/howto-detect-heteroscedasticity-and-rectify-it/ Present.

91. Robson, C. (2011).Real World Research. New Jersey: John Wiley \& Sons.

92. Saeedi, A., \& Mahmoodi, L. (2011). Capital structure and firm performance: Evidence from Iranian companies. International Research Journal of Finance and Economics, 70, 20-29.

93. Salifu, et al., (2007). Foreign exchange risk exposure of listed companies in Ghana.Bingley: Emerald Group Publishing Limited.

94. Salma, et Al., (2016). The Effect of Floating Exchange Rates on SME Performance.

95. Schechtev, C. (2014). Insufficient observations error with random effects model. Statalist. Retrieved from: www.statalist.org/forums/forum/general-statadiscussion/general/1420094-insufficientobservations-error-with-random-effects-model

96. Shaked, I., \& Michel, A. (1986). Multinational Corporations vs. Domestic Corporations: Financial Performance and Characteristics. Boston: Journal of International Business Studies.

97. Sidhu, C. H. et. al., (2014). Cola Company: Case Synopsis.

98. Stein, H. (2017).The Library of Economics and Liberty: Balance of payments. Retrieved from;

99. Stern, David I., From Correlation to Granger Causality (2011). (Crawford School Research Paper No. 13.). Canberra:Australian National University Retrieved from: 
"Effects of Exchange Rate Determinants on Financial Performance of Multinational Companies"

http://dx.doi.org/10.2139/ssrn.1959624

100.Stojanov, D. (2006). Relevance of Balance of Payments Theories from Classics up to The

101.Sun, P. \& Heshmati, A. (2010).International Trade and its Effects on Economic Growth in China. (IZA Discussion Paper No. 5151). Amsterderm: Elsevier.

102.Sunanda, S. (2010). International Trade Theory and Policy: A Review of the Literature. New York: Levy Economics Institute.

103.Tennet, J. \& Friend, G. (2005). Guide to Business Modelling. New Jersey: John Wiley \& Sons

104.Totonchi, J (2011) Macroeconomic Theories of Inflation. International Conference on Economics and Finance Research. Singapore: IACSIT

105.Ut, T.T. (2013). Data in a Research. Course hero. University of Newcastle. Retrieved from: https://www.coursehero.com
106. Valencia, F \&Laeven, L. (2012). Systemic Banking Crises Database: An Update. IMF Working Papers, 12(163), 33. doi: 9781475505054/1018-5941

107.Yusaff, et. al., (2012). A Critical Review of Multinational Companies, Their Structures and Strategies and Their Link with International Human Resource Management. London: SAGE Publication Ltd.

108.Zikmund, W. et.al. (2012) "Business Research Methods: with Qualtrics Printed Access Card". Boston: Cengage Learning.

109.Zubair, A. (2013). Causal relationship between stock market index and exchange rate: Evidence from Nigeria. CBN Journal of Applied Statistics. Abuja: Central Bank of Nigeria. 